\title{
1 Mining and peace: a scriptural reflection
}

\author{
Cardinal Peter K. A. Turkson
}

This book, born out of a larger project on mining and integral peace, addresses a fundamental question that has marked humanity's life and growth for decades, centuries, and millennia. Indeed, in terms of the human being's relationship with the earth, besides agriculture which provides nourishment for human existence, mining and mines dominate human activity on the land, providing material for tools, instruments, building, and decoration. So indicative were metals of human ingenuity and technological growth in the past that they gave their names to the different ages and periods of civilizations in human history. Thus, there was a movement from a Stone Age through a Copper Age, a Bronze Age, and an Iron Age. Classical literature also referred to a Silver Age and a Golden Age. Each of the different ages of history was characterized by the prevalent object or metal in use, even if it must be recognized that this development and history of the discovery of metals did not happen homogeneously in all geographical areas. Nevertheless, and with the necessary caveat, it is not wrong to assert that, from its beginning, human life has been associated to varying degrees with the discovery, production, and use of minerals and metals. And since not all places on earth are equally endowed with these deposits, mining gave rise to vigorous trade early in human history. Trade in minerals and metals continues to our own day, since we cannot do without them, even if the industry is fraught with tensions and conflicts between communities and businesses over land-use, and is marked by an ambiguity of purpose in the dignity-deficit with which it tends to leave communities and the environment.

In what follows, and by way of a prelude to the essays in this book, I shall modestly and briefly present the way this industry and the minerals which give rise to it are used to present phases of religious history in the Bible and some of its fundamental teachings, such as the transcendental character of God's covenant law, as wisdom, and the perfection of his presence, as pure gold, through redemption in Christ.

DOI: $10.4324 / 9781003094272-1$ 


\section{The wealth of creation and the goodness of the "land of promise"}

In the second account of creation (Gen. 2:4bff.), God creates a garden, which was destined to be the home of Adam, whom God created from the dust of the earth and made a living soul. The river that waters the garden breaks up into four rivers on leaving the garden. One of these tributaries, called Pishon, is reported to be flowing through a land endowed with minerals: "The name of the first is the Pishon; it winds through the entire land of Havilah, where there is gold. The gold of that land is good; bdellium and onyx stones are there" (Gen. 2:11-12). ${ }^{1}$ Since the mention of the other three rivers and where they flow are not followed by any indication of their properties, some commentators consider the mention of gold after Havilah to be a later addition. The canonical form of the account, however, would have us recognize that the earth (God's creation) did not only consist of vegetation, animals, birds, fishes, and the human person. God's creation (the earth) also contained precious minerals: a notice that prepares for the metallurgical work of Tubal-Cain (Gen. 4:22). Thus, if the second account of creation may be related with the first account (Gen. 1-2:4a) and considered "good," then the creation of an earth endowed with minerals and different metals, including those, like uranium, which can be used in nuclear weapons but also for peaceful purposes, is part of God's good purpose for the life of humanity on earth.

But in the general scheme of things in the Bible, the story of the creation of heaven and earth in the Book of Genesis, as the setting for human existence and of humanity's relationship with God, leads to the creation of a new heaven and a new earth in the Book of Revelation, as the goal and the fulfillment of history through redemption in Jesus Christ. Thus creation, with all its endowments and in all its goodness, quickly came to languish and to live under a curse for the sins of its inhabitants (Is. 24:3ff.). Since then, creation "awaits in eager expectation for the revealing of the children of God; for the creation was subjected to futility...in hope that creation itself will be set free from its bondage to decay and will obtain the freedom of the glory of the children of God" (Rom. 8:19-21). The earth and its endowments now exist under the stewardship of humanity in bondage to sin; and, as Pope Francis $(2015, \mathbb{2}$ ) observes, it is "the violence present in our hearts, wounded by sin," that is "reflected in the symptoms of sickness evident in the soil, in the water, in the air and in all forms of life." Living in bondage to sin, the human person's relationship with the earth and its resources, and his/her treatment of them, reflect his/her bondage, which is essentially the lack of justice towards God, towards one another, and towards creation. Set within this relationship, mining can reflect this bondage to sin; but it can also reflect the industry's response to a call to share in the vocation of humanity to redemption and to freedom to live in holiness and justice. (cf. Lk. 1:75). 
Subsequently, the stories of the patriarchs attest to the possession of precious minerals as a sign of wealth (Gen. 13:2) and their use for commerce and transactions (Abraham's purchase of land [Gen. 23:16]; Jacob's purchase of land [Gen. 33:19]). The Exodus story continues to attest to the use of precious minerals as a symbol of wealth. The Israelites receive gold and silver from their neighbors on the eve of their departure from Egypt (Ex. 11:2), which will contribute to Aaron's making of the golden calf (Ex. 32) and the decoration of the Tabernacle (Ex. 35:24ff.).

But reference to the earth's endowment with mineral wealth comes up again in God's presentation of the "land of promise" to Moses: a land with wheat and barley, vines and fig trees, pomegranates, olive oil, and honey; a land where bread will not be scarce and you will lack nothing; a land where the rocks are iron and you can dig copper out of the hills (Dt. 8:9, cf. too, 8:13). The minerals, like the fertility of the land, represent the goodness of the promised land; and they are a covenant gift of God and a sign of God's gratuitous love, which is meant to be received in grateful obedience and fidelity. The warning about prostituting God's covenant gift is severe! (Dt. 8:13-14).

Postponing for a later consideration the religious values of these minerals, we may note here that the warning about abusing the good things of the land of promise is linked to an invitation to reckon also with the purpose of the use of created goods. Created goods are bestowed on the human family, especially in the context of the covenant, as an expression of God's benevolent goodness, and they are meant to be received with gratitude and in faithfulness to God, and used with concern and care for the rest of creation.

\section{Mining and the contrast between earthly treasure and divine wisdom (Job 28)}

The notices above about the endowment of creation and the land of promise with precious minerals and metals are complemented in Israel's pre-exilic and post-exilic histories by a lot of data about the abundant use of precious minerals in financial transactions, in temple and palace decorations, in votive offerings, and in household utensils. ${ }^{2}$ The golden age of Israel's history, the reigns of David and Solomon, came during the Iron Age in world history. It was a period of great opulence and accumulation of wealth. David stored gold and precious stones for Solomon's building of the temple of the Lord (1 Chr. 22). The Queen of Sheba testified to the opulence of the palace of Solomon and the temple, and bestowed on him more wealth (1 Kg. 10; 2 Chr. 9). Biblical archeologists identify Eilat, the southern tip of the Dead Sea in the Jordan valley, as an attested mining site in ancient Israel-but it was for copper. Accordingly, the gold, silver, and precious minerals in the palaces and in the temple in ancient Israel (2 Kg.23:33, 35; 24:13-14; 25:13-16; cf. Dn.5:1-4) must have arrived there from tributes, gifts, and trade. 
But it is Job 28 that provides a rare disclosure of the art and skills of mining in ancient Israel and in the Middle East. This passage affirms that Wisdom is divine, and is inaccessible to humanity despite its great efforts and marvelous skills, such as those it displays in mining precious minerals. Human success at mining precious minerals, as hidden and remote as they are, does not suffice to give the human person access to Wisdom, because Wisdom transcends human efforts and labor. To make this point, Job 28 refers to the mining of silver, gold, iron, and copper: "Surely there is a mine for silver, and a place for gold that they refine. Iron is taken out of the earth, and copper is smelted from the ore" (Job 28:1-2); and proceeds to describe the details of shaft mining: "Man puts an end to darkness and searches out to the farthest limit the ore in gloom and deep darkness. They open shafts in a valley ... they sway suspended ... They put their hand to the flinty rock, overturn mountains by the root" (Job 28:3-9). The challenges of this activity to the environment, to development, and to the dignity of the miners are as real in this passage as they are today.

With reference to mining and development and the dignity of people, it is very striking how the conduct described in Job 28 readily calls to mind the words of Pope St. Paul VI $(1967, \$ 25)$ in his encyclical letter on development, Populorum Progressio: "By dint of intelligent thought and hard work, man gradually uncovers the hidden laws of nature and learns to make better use of natural resources. As he takes control over his way of life, he is stimulated to undertake new investigations and fresh discoveries, to take prudent risks and launch new ventures, to act responsibly and give of himself unselfishly." What Paul VI says here about industrialization and technological growth applies also to the mining industry; and the challenges which he goes on to identify, as bedeviling industrialization with a human face, also bedevil the mining industry, causing tensions and conflicts with local communities. The challenges which the pontiff draws attention to are "profit as the chief spur to economic progress, free competition as the guiding norm of economics, and private ownership of the means of production as an absolute right, having no limits nor concomitant social obligations” (\$26).

But Job's message is clear: despite the preciousness and great value of the minerals and the skills displayed in their mining and acquisition, they remain created gifts, created activities, and created skills, incomparable with and not to be substituted with Wisdom (Job 28:12. cfr. Prov. 8:10-11) and the search for it. As a divine attribute, Wisdom and the path to it (the fear of the Lord) are inaccessible to humans (Job 28:12ff.; cf. Baruch 3:15ff.). It is bestowed only as gift! Solomon prayed for it (1 Kg. 3:9), and God bestows it gratuitously on his people (Baruch 3:36-4:4).

\section{The gift of gold, frankincense, and myrrh to baby Jesus}

The three men whom the Gospel of Matthew calls "magi” (Mt. 2:1-12), came from the East on seeing the newborn king of the Jews' star in the east 
or at its rising (Mt. 2:2). Helped on by the word of prophecy to get to Bethlehem, they offer the baby Jesus gifts which are consistently described as gold, frankincense, and myrrh. While the three gifts were valuable items traditionally offered to a deity in ancient times, their presentation to Jesus symbolizes the magis' beliefs about the Christ-child's identity and his mission. Frankincense, used in worship, is offered to Jesus in recognition of his divinity. Myrrh makes us think of the "myrrh and aloe" which Joseph of Arimathea and Nicodemus brought for Jesus' burial (Jn. 19:38-39), and it is in recognition of Jesus' death, as messianic and redemptive. Gold, which is rust-free and non-corrosive, is offered in recognition of the kingship of Jesus, which, according to prophecy (Mt. 2:6; Lk. 1:33; Is. 9:7), is lasting, enduring, and eternal.

\section{Metals and stones in the new creation: the splendor of the new heaven and new earth (Rev. 21)}

The account of creation in Genesis, with which human history on earth begins, concludes with the preparation of a garden in Eden to be the home of Adam (joined later by Eve) whom God has created. This garden home was endowed with mineral wealth (Gen. 2:11-12), as we have seen. The end of human history is presented in the Book of Revelation as a new beginning of human history in a new heaven and a new earth, since the first heaven and the first earth have passed away (Rev. 21). Just as at the first creation (Gen. 1-3) God prepared a garden home for Adam, so does God prepare a new home, the holy city, the new Jerusalem (Rev. 21:2) for humanity redeemed: "those whose names are written in the Lamb's book of life" (Rev. 21:27).

What attracts our attention at this point is the presence or the place of precious stones and metal in the presentation of the two dwellings: the garden home of Adam and the holy city of humanity redeemed. While in the first (Gen. 2:10-13), the river Pishon flows around the whole land of Havilah, where there is gold, bdellium, and onyx, in the holy city of God's redeemed, the city itself and its street are gold, and its wall is built of jasper, whose foundations are "adorned with every jewel..." (Rev. 21:18-21). Adam's garden home is endowed with and possesses gold and precious stones; the holy city that comes down from heaven, by contrast, is wrought in gold and is gold itself. Thus, while in Eden gold has the sense of a mineral resource deposit and an endowment of a terrain that can be mined, in the holy city from heaven, which is gold and which is adorned with "the glory of God and a radiance like a very rare jewel, like jasper, clear as crystal" (Rev. 21:11), gold cannot have the sense of a mineral endowment to be mined. The holy city, which is gold and whose wall is built of jasper..." (Rev. 21:18-21), is also "a bride adorned for her husband" (Rev. 21:2). The holy city is the "bride, the wife of the Lamb" (Rev. 21:9). Thus, the gold of the holy city cannot have the physical sense 
of mineral deposit; it must have the sense of a symbolism, whose meaning we may now briefly explore.

\section{The golden adornment of the tabernacle and the temple prefigures the boly city}

At the behest of God (Ex. 25), Moses took donations of gold, silver, bronze, textiles, skins, and acacia wood from the people to build the ark of the covenant, the table of the bread of presence, and the lampstands in the tabernacle; and, as the dwelling place of God among his people (Ex. 25:8), the content of the tabernacle was wrought in pure gold. When wood was used, it was overlain with gold.

Similarly, when Solomon built the temple of the Lord, in the fourth year of his reign, as God's dwelling (1 Kg. 6:13), he overlaid "the whole house... the Cherubim, the floor of the house with gold $(1 \mathrm{Kg} .6: 22$, $28,30)$. For, as the metal that neither rusts nor corrodes, as already observed, gold was not just a store of value; it signified lasting value. Accordingly, when kings did accumulate gold, it gave expression to their splendor, their power and might. But, most importantly, they also sought to appropriate for their reigns the metal's attribute of a lasting permanence. When, however, the precious metal is predicated of God and of his presence, the unchanging and lasting character of the metal, as well as its brilliance, finds its worthiest symbolism, expressing the eternity, enduring perfection, and the glory of God.

Thus, the "holy city: the bride of the Lamb" of the Book of Revelation is pure gold, because it has been made perfect and eternal by Christ's passion. ${ }^{3}$ It is not of any man's making. It is pure gold by reason of its sharing in the nature of the divinity that dwells there. Secondly, and by contrast with its prefiguration in the Old Testament, as well as other instances of human accumulation of gold as wealth, we need to distinguish between being something and having something. On earth, gold is possessed (having); and it is used as such. In the new creation, the holy city is gold (being), namely, completely invaded and filled with divine presence. The latter is an expression of the nature and essence of the holy city, where the purity of the minerals expresses the fullness of God's presence. The former instance of "having" entails an invitation, indeed, a vocation, to pass from "having" to becoming: to "being" the value and quality of what is possessed.

\section{Conclusion}

The symbolic use of precious metal in the Scriptures ascribe to the metal a character and a value that transcend its earthly value and usage, namely, as mere source and instrument of wealth. The Scriptural usage of the metal and others in its family appeals to a character of the metals 
which underlie their earthly usage, as valuable, precious, and lasting. But, ironically, these characteristics of the precious metals make them outlive the human person, who cherishes them and amasses them without, however, being able to share in their non-corrosive and incorruptible nature. Gold and the precious metals attain their true destiny, as it were, in the Book of Revelation, when they express the truly eternal, non-corrosive, and incorruptible kingdom of God.

In this sense, can the industry that seeks with such skills and dexterity to possess these precious metals be guided by some other objective and vision, besides that of possession or having wealth on earth? Can the industry also be inspired and guided by the values of the kingdom of God, where these precious metals are truly at home, as it were, giving expression to the heavenly Jerusalem, the holy city of God's redeemed, as the Scriptures suggest? Can the industry adopt values of the kingdom of God as guiding principles: the "common good," the "universal destination of the goods of the earth," "peace and justice," "concern for the poor," and "care of creation, our common home"?

\section{Notes}

1 Biblical references are from The New Oxford Annotated Bible, edited by Michael Coogan (2001).

2 Cf. Gen 23:16; 33:19; Ex 38:25; Lev 27:25; Jdg 8:26; 1 Sam 9:8; Ezek 45:12; 1 Chr 21:25; 29:7; Ezra 2:69; Neh 5:15; 7:70; Tob 5:15; Job 42:11; Mt 10:9.29; $17: 24 ; 18: 24 ; 20: 13 ; 21: 12 ; 22: 19 ; 26: 15$; Lk 10:35; 12:6; 19:13; Acts 19:19

3 The idea of proving the worth of one's faith and fidelity to God through testing and trials is well attested in Scriptures (2 Chr 32:31; Jer 9:7; James 1:12; $1 \mathrm{Pt}$ 1:6-7; 1 Pt 4:12-13; 1 Pt 5:10; Rev. 3.10). Often, the purification, testing, and the assaying of precious metals, like gold and silver, provide analogies for the testing of faith. Faith, tested and proven, is analogically presented as gold or silver tested and purified by fire (Ps 66:10-12; Prov 17:3; Job 23:10; Zech 13:9; 1 Pt 1:6-7; $\operatorname{Rev} 3: 18)$.

\section{References}

Coogan, Michael, ed. 2001. The New Oxford Annotated Bible, New Revised Standard Version with the Apocrypha. New York: Oxford University Press.

Francis. 2015. Laudato Si'. http://www.vatican.va/content/francesco/en/encyclicals/ documents/papa-francesco_20150524_enciclica-laudato-si.html.

Paul VI. 1967. Populorum Progressio. http://www.vatican.va/content/paul-vi/en/ encyclicals/documents/hf_p-vi_enc_26031967_populorum.html. 